\title{
Pattern and Severity of Vaso Occlusive Crisis in Paediatric Sickle Cell Anaemia Patients
}

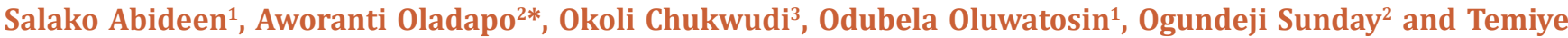 \\ Edamisan $^{4}$
}

${ }^{1}$ Clinical Science Department, Nigerian Institute of Medical Research, Yaba, Lagos, Nigeria

${ }^{2}$ Department of Haematology, University College Hospital, Ibadan, Nigeria

${ }^{3}$ Lifeline Children's Hospital, Lagos, Nigeria

${ }^{4}$ Department of Paediatrics, Lagos University Teaching Hospital, Lagos, Nigeria

Submission: May 18, 2020 Published: June 01, 2020

*Corresponding author: Aworanti Oladapo, Department of Haematology, University College Hospital Ibadan, Nigeria

Abstract

Background: Sickle cell anemia (SCA) remains an inherited disease of public health significance in sub-Saharan Africa with Nigeria accounting for the significant burden of the disease globally. Acute painful crisis/event remains the hallmark of the disease with significant impact on physical and psychosocial wellbeing of both the children and the parents/caregivers despite advancement in care. The pattern and severity of acute painful event/VOC among children living with sickle cell anaemia were evaluated with a view to understand the manifestations of SCA in this group of patients.

Methods: This was a prospective cross-sectional study and involved patients who presented at the emergency room, or out-patient unit of the Paediatrics Department of the Lagos University Teaching Hospital, Idi-Araba Lagos with acute painful crisis over a nine-month period (March 2015 - November 2015).

Result: The participants mean age was $8 \pm 7$ years with male to female ratio of 1.1. The distribution of pain with respect to anatomic sites were the extremities only 47(43.4\%), extremities and other sites 27 (25.5\%), abdomen 13(12.3\%) and chest 12(11.3\%). Sixty-six (62.3\%) children with SCA presented with moderate pain intensity, $30 \%$ with severe pain intensity and $4.7 \%$ with mild pain intensity. Most of the children presented at the hospital within four days of pain onset.

Conclusion: The commonest site of pain among children living with homozygous sickle cell anaemia is in the extremities. Most patients presented within the first four days of onset of pain and with moderate intensity.

Keywords: : Children; Sickle cell; Pain; Severity; Location

\section{Introduction}

Sickle cell anaemia (SCA) is a homozygous form of sickle cell disease which is an inherited autosomal recessive disorder. $[1,2]$ The disease is prevalent amongst people of Sub-Saharan Africa, Mediterranean basin, Arabian Peninsula, and India subcontinental ancestral origin. Sub-Saharan Africa however accounts for the largest burden of disease worldwide with about 200,000 of the 300,000 live births delivered with sickle cell disease yearly. [35] Nigeria accounts for the highest disease burden and mortality in children below the ages of five years with sickle cell anemia [6-8]. SCA is chronic hemolytic disease with an ongoing risk of acute manifestations and multi-organ dysfunctions $[1,9,10]$.
Acute Painful episodes or vaso-occlusive crisis [VOC] remain the hallmark of SCA worldwide [11,12]. It starts at infancy and spans throughout the patient's lifetime. Its onset can be acute, subacute, chronic, or episodic and its predisposing factors include infections, extremes of weather, stress, which could be emotional, psychological, or physical. $[1,9,13]$. The pain itself could be somatic, visceral, neuropathic, or even iatrogenic with devastating effects on the physical, psycho-social, financial, and quality of life of the patients, care givers and the entire society due to recurrent hospitalization $[11,14]$. The mainstay in the management of pain in SCA includes hydration and analgesics with other pain controlling measures; this is in addition to plausible treatment 
for the predisposing conditions which include administration of appropriate antibiotics to infection, treatment of malaria, red cell transfusion, and the provision of adequate psychosocial support $[13,15-17]$. Similarly, there are preventive measures that could be taken against pain and other vaso-occlusive crises, these include adequate oral fluid intake, avoidance of extremes of weather and stressful events, the use of antimalarial and pneumococcal prophylaxis, vaccination against pneumococcal and meningococcal organisms, use of hydroxyurea, chronic or exchange blood transfusion and continuous education and counseling $[13,15,18]$. This study was undertaken to evaluate the pattern and severity of acute painful crisis/VOC among children living with sickle cell anemia presenting to Lagos University Teaching Hospital Lagos with a view to understand the manifestations of SCA in this group of patients. It was hoped that the findings from this study will contribute to knowledge of the disease in children with sickle cell anemia in Nigeria.

\section{Materials and Methods}

This was a prospective cross-sectional study and involved patients who presented at the emergency room, or out-patient unit of the Pediatrics Department of the Lagos University Teaching Hospital, Idi-Araba Lagos with acute painful crisis over a nine month period (March 2015-November 2015).Vaso occlusive crisis is defined as occurrence of pain in the extremities, back, chests or any other parts of the body that led to hospital presentation and/or admission and could not be explained by any other disease entity except sickle cell disease [19]. The respondents were known SCA previously diagnosed in the hospital between ages 1-18 years, and regularly attend follow- up outpatient clinic of the paediatric sickle cell clinic. All SCA patients with confirmed chronic disease [CVA, CKD, chronic heart disease] and the newly diagnosed SCA children in acute painful crisis were excluded. The attending physicians interviewed the patients and questionnaires were completed. Ethical approval was obtained from Lagos University Teaching Hospital Health Research and Ethic Committee [LUTH HREC]. After an initial stabilization of the child, the details of the study were communicated to the parents/guardian and patients, consent and assent forms were completed by parents/guardians and patient aged 10-18years for subjects who satisfy the study criteria. A detailed clinical examination including the pain score was carried out in the Children Emergency room or on the wards and documented. The examination included anthropometric measures. The severity of pain in children aged 1-7years was assessed using the FLACC pain scale while Wong -Baker pain rating scale was used for children aged 8-18years. The FLACC pain scoring was done by 2 independent clinical investigators while the Wong -Baker was by the subject in pain. The children were managed as per the protocol of the institution [Children Emergency and the Haematology Units] in order to maintain the best clinical practice and to meet the patients` requirements.

\section{Results}

A total of one hundred and six children with VOC were enrolled in the study. The mean age of the study participants was $8 \pm 7$ years and the age distribution showed that $36(34 \%)$ children each were in the 1-5years and 6-10years groups and 34(32\%) were in the adolescent age group (11-18years). The male to female ratio was 1:1. Table 1 below shows the socio-demographic and anthropometric characteristics of the patients

Table 1: Demographic and anthropometric characteristics of study participants.

\begin{tabular}{|c|c|}
\hline Characteristics of SCA Patients & N (\%) \\
\hline Age at enrollment: Median (IQR] years & $8(1-18)$ \\
1-5 years & $36(34 \%)$ \\
6-10 years & $36(34 \%)$ \\
11-18years & $34\{32 \%)$ \\
\hline Gender & \\
Male & $56(50 \%)$ \\
Female & $56(50 \%)$ \\
\hline BMI [Kg/m $\left.\mathbf{m}^{2}\right]$ & \\
Low & $95(89.6 \%)$ \\
Normal & $10(9.4 \%)$ \\
Overweight & $1(1 \%)$ \\
\hline
\end{tabular}

\section{Location of the vaso-occlusive crisis}

Out of the 106 patients that presented in VOC, most of the respondents (51\%) presented with pain in the extremities (upper and lower) while the rest presented with pain in the chest, back, abdomen and penile shaft. Only 2 patients presented with back pain, 21 patients presented with pain in the lower extremities only and 17 patients had pain in the upper extremities only. About one tenths of the respondents presented with pain in three or more regions of the body. The most frequent location of the pain was in the lower extremities and the least frequent site of pain was penile shaft (priapism). The location of pain is as shown in Table 2.

Table 2: Gross distribution of pain location.

\begin{tabular}{|c|c|}
\hline Location of Pain & (\%) \\
\hline Extremities [Upper and Lower Limbs] & 51.2 \\
\hline Abdomen & 18.6 \\
\hline Chest & 16.3 \\
\hline Back & 13.4 \\
\hline Penile & 0.6 \\
\hline
\end{tabular}

\section{Duration of pain}

Fifty-nine $(55.7 \%)$ children presented in the hospital within 2-4 days of the onset of VOC, while $4(3.8 \%)$ of the patients presented after 7 days of onset of pain and only 14\% presented within the first day of pain. Table 3 below shows the duration of pain prior to presentation in the hospital. 
Table 3: Duration of Pain at Hospital Presentation.

\begin{tabular}{|c|c|}
\hline Duration of Pain [in Days] & Frequency N (\%) \\
\hline$\leq 1$ & $14(13.2)$ \\
\hline $2-4$ & $59(55.7 \%)$ \\
\hline $5-7$ & $29(27.4 \%)$ \\
\hline$>7$ & $4(3.8 \%)$ \\
\hline
\end{tabular}

\section{Severity of pain}

With respect to the severity of acute painful crisis, most of the patients (63.2\%) presented with moderate intensity of bone pain, while (32.1\%) presented with severe pain intensity and only $4.7 \%$ presented in mild bone pain intensity. (Figure 1)

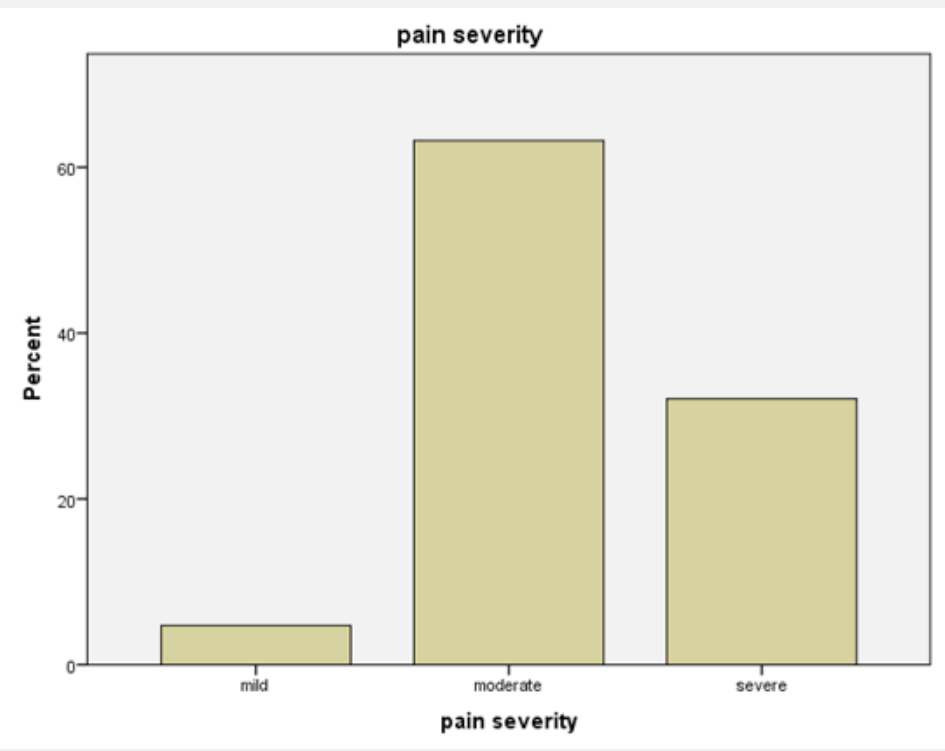

Figure 1: Severity of Pain in the Respondents.

\section{Discussion}

The index study is to evaluate the pattern and severity of acute painful crisis among children living with sickle cell anaemia using validated pain assessment tools; FLACC and Wong baker faces for children [1-7 years] and [8-18years] respectively. The anthropometric characteristics of the participants showed that most sickle cell anaemia patient are underweight, this could be as a result of inadequate growth hormone secretion, increased demand for nutrition and increased rate of metabolism, this finding is consistent with previous studies done by Odetunde IO \& Andrea Zivot et al, $[20,21]$ where most patients reviewed were found to be underweight. In this study, the commonest sites of pain were the extremities [upper and lower limbs] though pains in the lower limbs were commoner. This could be as a result of increased interruption of blood flow to the long bones because of the sinusoidal circulation in these long bones. Other sites in order of frequency include abdomen, chest, back and penile shaft as previously documented [22]. These findings are consistent with previous studies done by Salman et al, [23] in Iraq, Jaiyesimi et al, [24] in Oman, and in another study with the paediatric age group in America and Europe [25] but contradicts the finding in some other previous studies that identified chest, abdomen and back as the commonest site of pain. The different findings in the publications explain the plausible variability in pain location in different individuals living with sickle cell anaemia. Also, most of the patients had pain in two or more sites, this is consistent with findings previously reported [26]. Most of the participants presented to the hospital within 2-4 days of onset of pain, this is because most of the patients and the parents/guardians take or give some form of analgesics prior to presentation in the hospital. 
Moreover, vaso-occlusive crisis are initially mild at the onset and progressively increase in intensity over time. This finding is in concordance with previous works done by Jacob E et al. [27,28]. A significant proportion of the participants presented with moderate pain intensity. This is alluded to routine health education at sickle cell support groups on the use of analgesics for mild pain but when there is no improvement, they are to present in the hospital. However, some vaso-occlusive crises could be severe from onset and necessitate hospital presentation within the first day of pain. In this study, about one-third of the patients presented with severe pain. This could be responsible for presentations within the first 24hours of the painful crisis. This finding is consistent with previous reports by Oshikoya et al. [29] in Nigeria, Abdo et al., in Jordan [30], Jacob \& Neri et al. [27,31] in studies in the USA. This finding is in congruent with other reports evaluating the intensity of pain at presentation among children with sickle cell anaemia presenting in acute painful crisis despite the use of different pain assessment tools. [32-34]

\section{Conclusion}

In conclusion, the study further buttresses the findings that most SCA patients are underweight and the extremities are the commonest site of acute painful event. Most patients also present promptly to the hospital. The need for health education and prompt management of acute painful events in children with sickle cell anaemia will promote their total physical, psychosocial wellbeing of the children and their parent/caregivers.

\section{Limitations}

This study is characterized by some limitations; the proportion of the children who presented in acute painful crisis that required admission and the duration of the hospital stay with respect to resolution of pain or development of other clinical condition were not documented. This is a hospital-based study, a community study is needed to capture the patients not on routine follow up in our hospital.

\section{Acknowledgement}

We appreciate all the children and the parents/caregivers who participated in the study and who continue to trust the Paediatric team of the Lagos University Teaching Hospital [LUTH] with the care of their children. Our sincere gratitude to the Paediatric Nurses and Medical doctors in the children emergency, Paediatric haematology outpatient and inpatient unit for the support through this work.

\section{Sponsorship}

There was no grant or sponsorship for this work, it was selfsponsored.

\section{References}

1. Graham RS, Sickle cell disease, In Graham RS. Sickle cell disease $\left(1^{\text {st }}\right.$ Edn.), USA: Oxford University Press; 1985: 1-475.
2. Quinn CT, Miller ST (2004) Risk factor and prediction of outcome in children and adolescent with Sickle cell anaemia. Hematol Oncol Clin N Am 18(6): 1339-1354.

3. World Health Organization (2013) World Health Statistic Annals: WHO.

4. Piel FB, Hay SI, Gupta JS, Gupta GS, Weatherall DJ, et al. (2013) Global burden of sickle cell anaemia in children under five PloS Med 10(7): $1-14$.

5. Piel FB, Patil AP, Howes RE, Nyangiri OA, Gething PW, et al. (2013) Global epidemiology of sickle cell haemoglobin in newborn; A Contemporary geo-statistical modal-based map and population estimates. Lancet 381: $142-157$

6. Rees DC, Williams TN, Gladwin MT (2010) Sickle cell disease. Lancet 376: 2018-2031.

7. Akinyanju OO (1989) Profile of sickle cell disease in Nigeria. Ann N Y Acad Sci 565: 126-136.

8. United Nations General Assembly 2009. Recognition of sickle cell anaemia as a public health issue.

9. Samir KB, Muge RK, Morton FG, Gerard AL, Dampier C (2012) Beyond the definitions of the phenotypic complications of sickle cell disease: An update on management. Scientific World Journal 1-15.

10. Samir KB, Susan L, Lenette JB, Dampier DC, Heeney MM, et al. (2010) Definition of phenotypic manifestation of sickle cell disease. Am J haematol 85(1): 6-12.

11. Ballas SK (2011) Update on pain management in sickle cell disease. Haemoglobin 35(5): 520-529.

12. Salako A, Aworanti O, Opaneye B, Abimbola S (2019) Pattern of Childhood Morbidity in a Private Paediatric Centre in Lagos Nigeria. Saudi J Nurs Health Care 2(8): 276-283.

13. Odievre M, Verger E, Silva-Pinto AC, Elion J (2011) Pathophysiological insights in sickle cell disease. Indian Journal of Medical Research (IJMR) 134(4): 532-537.

14. Day TG, Thein SL, Dick MC, Height SC, O'Driscoll S, et al. (2011) Changing patterns of hospital admissions of children with sickle cell disease over the last 50years. J Paediatrhaematoloncol 33(7): 485-491.

15. Jane SH, Winfred WC Sickle cell anaemia and other sickling syndromes. In Greer JP, Arber DA, Glader B, List FA, Means RJ Jnr, Paraskevas F, Rodger GM Wintrobe's Clinical Hematology $\left(13^{\text {th }} \mathrm{Edn}\right)$.

16. Wallen GR, Middleton KR, Ames N, Brooks TA, Hadel O (2014) Randomized trial of hypnosis as pain and symptom management strategy in adults with sickle cell disease. Integrative Medicine Insights 9: 25-33.

17. Gladwin MT, Kato GJ, Weiner D, Onyekwere DC, Dampier C, et al. (2011) Nitric Oxide inhalation in acute treatment of sickle cell pain; A randomized clinical trial. JAMA 305(9): 893-903.

18. Philip L (2011) Haemoglobinopathy In Philip Lanzkowsky Manual of Paediatrics Haematology and Oncology ( $5^{\text {th }}$ Edn.), USA: Academic Press, pp. 201-296.

19. Alagbe AE, Olaniyi JA, Aworanti OW (2018) Adult Sickle Cell Anaemia Patients in Bone Pain Crisis have Elevated Pro-Inflammatory Cytokines. Mediterr J Hematol Infect Dis 10: e2018017.

20. Odetunde IO, Chinara JM, Achigbu KI, Achigbu EO (2016) Body Mass Index and other Anthropometric variables in Children with Sickle Cell Anaemia. Park J Med Sci 32(2): 341-346.

21. Andrea Zivot, Nataly Apollonsky, Edward Gracily, Deepti Raybagkar (2017) Body Mass Index and the association with Vaso-occlusive crises in Paediatric Sickle cell Disease. J Pediatr Hematol Oncol 39(4): 314317. 
22. Hankins JS, Wang WC (2014) Sickle Cell Anaemia and other Sickle Syndrome: Hereditary Disorders of Hemoglobin Structure and Synthesis 2014: 823-861.

23. Salman ZA, Hassan MK (2015) Hospitalization Events among Children, and Adolescents with Sickle Cell Disease in Basra, Iraq. Anaemia. 2015: 1-8.

24. Jaiyesimi F, Pandey R, Bux D, Sreekrishna Y, Zaki F, et al. (2002) Sickle cell morbidity profile in Omani children. Annals of Tropical Paediatrics 22(1): 45-52.

25. Fosdal MB, Wojner-Alexandrov AW (2007) Events of hospitalization among children with sickle cell disease. Journal of Paediatric Nursing 22(4): 342-346.

26. Yale SH, Nagib N, Guthrie T (2000) Approach to the Vaso-occlusive crisis in Adults with Sickle Cell Disease. Am Fam Physician 61(5): 1349-1356.

27. Jacob E, Mueller BU (2008) Pain Experience of Children with Sickle Cell Disease Who Had Prolonged Hospitalization for Acute Painful Episodes. Pain Medicine 9(1): 13-21.

28. Jacob E, Miaskowski C, Savedra M, Bayer JE, Treadwell M, et al. (2003) Changes in intensity, location, and quality of vaso-occlusive pain in children with sickle cell disease. Pain 102:187-193.
29. Oshikoya KA, Edun B, Oreagba IA (2015) Acute pain management in children with sickle cell anaemia during emergency admission to a teaching hospital in Lagos Nigeria. S Afr J Child Health 9(4): 119-123.

30. Abdo S, Nuseir KQ, Altarifi AA, Barqawi M, Ayoub NM et al. (2019) Management of Sickle Cell Disease Pain among Adolescent and Paediatric Patients. Brain Sci 9(182): 1-11.

31. Neri CM, Pestieau SR, Young H, Elmi A, Finkel JC et al. (2014) Low-dose Ketamine for Children and Adolescents with Acute Sickle Cell Disease Related Pain: A Single Centre Experience. J AnesthClin Res 5(3): 394.

32. Vijenthira A, Stinson J, Friedman J, Polazzi L, Taddio A et al. (2012) Benchmarking pain outcomes for children with sickle cell disease hospitalized in a tertiary referral pediatric hospital. Pain Res Manage 17(4): 291-296.

33. Walco GA, Dampier CD (1990) Pain in children and adolescents with sickle cell disease. a descriptive study. J Pediatr Psychol 15: 643-658.

34. Ballas SK, Delengowski A (1993) Pain measurement in hospitalized adults with sickle cell painful episodes. Ann Clin Lab Sci 23: 358-361.
Your next submission with Juniper Publishers will reach you the below assets

- Quality Editorial service

- Swift Peer Review

- Reprints availability

- E-prints Service

- Manuscript Podcast for convenient understanding

- Global attainment for your research

- Manuscript accessibility in different formats

( Pdf, E-pub, Full Text, Audio)

- Unceasing customer service

Track the below URL for one-step submission https://juniperpublishers.com/online-submission.php 